\title{
Blood Malondialdehyde, Reproductive, and Lactation Performances of Ewes Fed High PUFA Rations Supplemented with Different Antioxidant Sources
}

\author{
D. M. Fassah ${ }^{\mathrm{a} *}$, L. Khotijaha ${ }^{\mathrm{a}}$, A. Atabany ${ }^{\mathrm{b}}$, R. R. Mahyardiani ${ }^{\mathrm{a}}$, R. Puspadini ${ }^{\mathrm{a}}$, \& A. Y. Putra ${ }^{\mathrm{a}}$ \\ aDepartment of Nutrition and Feed Technology, Faculty of Animal Science, Bogor Agricultural University \\ ${ }^{b}$ Department of Animal Production and Technology, Faculty of Animal Science, Bogor Agricultural University \\ Jalan Agatis, Kampus IPB Darmaga, Bogor 16680, Indonesia \\ (Received 23-10-2014; Reviewed 09-02-2015; Accepted 05-03-2015)
}

\begin{abstract}
The aims of this study were to evaluate the effect of vitamin E (vit E) and black tea extract (BTE) as antioxidant sources in high poly-unsaturated fatty acid (PUFA) rations on blood malondialdehyde (MDA) concentrations and the performance of reproduction and lactation of Garut ewes. Twelve ewes on late pregnancy periods were divided into completely randomized design (CRD) with 3 treatments and 4 replicates. The treatments were control: basal diet without antioxidant, vit E: basal diet supplemented with vit E, and BTE: basal diet supplemented with BTE. The results showed that vit E and BTE supplementation did not affect blood MDA concentration of ewes on late pregnancy, lactation periods, and weaning periods. Antioxidant sources supplementation had no effect on ewe's nutrient intake, pre-lambing live weight change (LWC), and post-lambing average daily gain (ADG). Vit E supplementation had decreased the milk production, but both of antioxidant sources give positive effect on the milk composition. Nevertheless, the supplementation of vit E and BTE increased the twin type of birth. The vit E supplementation resulted higher lambing rate than BTE, although it had the highest mortality rate of twin lamb. BTE also had better lamb weaning weight than vit E. BTE and vit $\mathrm{E}$ gave similar results in ewes productivity on lactation period. In conclusion, this study confirmed that BTE was more effective used as antioxidant source than vit $E$ to prevent the oxidative reaction of PUFA. Vit E supplementation on high PUFA ration reduced ewes milk production but it had similar reproduction performance with $B T E$.
\end{abstract}

Key words: antioxidant, black tea extract, ewes, lactation, reproduction, vitamin E

\section{ABSTRAK}

Penelitian ini bertujuan untuk mengevaluasi pengaruh penambahan vitamin E (Vit E) dan ekstrak teh hitam (BTE) sebagai sumber antioksidan dalam ransum kaya poly-unsaturated fatty acid (PUFA) terhadap kadar malondialdehida (MDA) darah, performa reproduksi dan laktasi induk domba Garut. Penelitian ini menggunakan rancangan acak lengkap pola searah dengan 3 perlakuan dan 4 ulangan. Perlakuan yang diberikan adalah kontrol: ransum basal tanpa antioksidan, Vit E: ransum basal disuplementasi Vit E, dan BTE: ransum basal disuplementasi BTE. Hasil penelitian menunjukkan bahwa suplementasi Vit E dan BTE tidak mempengaruhi kadar MDA darah induk domba pada akhir kebuntingan, periode laktasi, dan pada saat periode sapih. Sumber antioksidan tidak berpengaruh terhadap konsumsi pakan, pre-lambing LWC dan post-lambing ADG induk domba. Suplementasi vitamin E menurunkan produksi susu, namun kedua sumber antioksidan memberikan dampak yang positif terhadap komposisi susu. Suplementasi Vit E dan BTE meningkatkan terjadinya kelahiran kembar. Suplementasi Vit E menghasilkan lambing rate yang lebih tinggi dari BTE, tetapi tingkat kematian anak yang tertinggi diantara perlakuan. BTE menunjukkan bobot sapih domba yang lebih baik dibandingkan Vit E. Suplementasi BTE dan Vit E menghasilkan produktivitas induk yang sama pada periode laktasi. Kesimpulan dari penelitian ini adalah BTE lebih efektif digunakan sebagai sumber antioksidan untuk menjaga reaksi oksidasi pada PUFA daripada Vit E. Suplementasi Vit E pada pakan kaya PUFA menurunkan produksi susu, namun menghasilkan performa reproduksi yang sama dengan BTE.

Kata kunci: antioksidan, ekstrak teh hitam, induk domba, laktasi, reproduksi, vitamin E

*Corresponding author:

E-mail: dilla.mareistia@hotmail.co.id 


\section{INTRODUCTION}

Nutritional levels of ewes in late pregnancy and lactation periods affected the energy reserves at born and lamb growth. Unfullfilled nutrient requirements for ewes affect placental size, foetal growth, foetal fat deposition, maternal udder development and milk production. Furthermore, it declined animal health and production performances. NRC (2007) recommends the ewes energy on late pregnancy is 1.5 times higher than maintenance. The fatty acids addition is one way to improve the feed energy. Hidayah et al. (2014) found that the supplementation of flaxseed oil protected with calcium soap resulted the high total volatile fatty acid which is indicating the highest supply of energy for ruminant. Our previous study indicated that non protected sunflower oil addition as the sources of essential poly unsaturated fatty acid (PUFA) improved reproductive performance of ewes, but the mortality rate was still high on birth and pre weaning periods. It is presumably due to the PUFA has not been used optimally.

The high metabolic demand in late pregnancy and lactation period also induced oxidative stress. Using high PUFA in the ration in these periods resulted in lipid peroxidation due to unbalanced condition between free radical and body antioxidant defense. Lipid peroxidation produces wide variety of aldehydes which can be formed as secondary products, such as malondialdehyde (MDA) (Ayala et al., 2014). This compound is widely used to determine the oxidation process in various condition. Higher oxidative stress during pregnancy and lactation increase blood MDA concentration and it is implicated in some diseases which cause both of maternal morbidity and mortality (Bhale et al., 2014; Bhuyar \& Shamshuddin, 2014; Yang et al., 2011).

Exogenous antioxidant could be added to reduce the negative effect of lipid peroxidation formation on high PUFA ration. The role of antioxidants is to neutralize the excess of free radicals, to protect the cells against their toxic effect and contribute to health prevention (Rao et al., 2011). Antioxidant prevents PUFA from oxidative reaction (Murray et al., 1993), so it reach optimum PUFA utilization. Exogenous antioxidant, such as vit E is commonly used. Vit E supplementation on high PUFA ration improves lamb birth weight (Carper et al., 2005).

Local plants are rich in phytochemical compounds, which can contribute to maintain the quality of nutrition and health. The use of plant extracts to inhibit the oxidation process is a nutritional strategy that is very interesting to be studied. Shahidi (2009) stated that the natural antioxidant compounds of plant origin generally a polyphenol compounds which capable to maintain and inhibit reactive oxygen species (ROS) formation thereby reducing the risk on immunity. Wang et al. (2013) reported green tea polyphenols improved pregnancy rates in bovine embryos which associated with the increase of antioxidant enzyme genes expression and decreased apoptotic index in bovine blastocysts. Sgorlon et al. (2006) stated that tomato pomace (lycopene) and grape polyphenols were able to counter balance oxidative stress in ruminants, inducing specific transcriptional activity of genes involved in oxidant defense. Last investi- gation reported the multimeric polyphenols, theaflavins and thearubigins on black tea had more antioxidant abilities (Frei \& Higdon, 2003), but rare study regarding its effect on ewes reproductive performances. The aim of this study was to compare the effect of vit E and BTE supplementation as antioxidant sources on high PUFA rations on the blood malondialdehyde (MDA) concentration, reproduction and lactation performance of Garut ewes.

\section{MATERIALS AND METHODS}

\section{Animals and Diets}

Twelve of 3-4 month gestations of Garut ewes were assigned into a completely randomized design with 3 treatments and 4 replications. The trial was lasted for 90 d. Ewes were housed in individual cages and had free access to drinking water.

Ewes were fed Brachiaria humidicola and concentrate containing 6\% sunflower oil. Each concentrate on each treatment was added with different antioxidant sources, namely: Control= basal diet without antioxidant source, vit $\mathrm{E}=$ basal diet supplemented with 500 ppm vitamin $\mathrm{E}, \mathrm{BTE}=$ basal diet supplemented 500 ppm $(37.5 \mathrm{~g} / 100 \mathrm{~g}$ polyphenol) black tea extract. BTE was extracted from black tea leaves, using ethanol extract by maceration method (BPOM, 2004). Chemical composition of B. humidicola and concentrate is shown in Table 1.

\section{Experimental Procedures}

Ewes were offered rations twice a day with $1 \mathrm{~kg} /$ day B. humidicola $(07.00$ and $16.00 \mathrm{~h})$ and ad libitum concentrate (refilled at 07.00, 12.00, and $16.00 \mathrm{~h}$ ). The residual feed was collected from the feeder daily. Chemical composition of concentrate and forage were determined by AOAC (2005). Ewes were weighed at the beginning and further once a week along the experimental period. The average of daily gain (ADG) and daily feed intake (ADFI) were recorded. The protein and TDN intake were calculated.

Individual blood samples were taken in the morning before feeding, from the jugular vein into a vacutainer. The blood samples were centrifuged at $3000 \mathrm{rpm}$ for $15 \mathrm{~min}$. The serum was separated and placed into

Table 1. Chemical composition of concentrate and forage (dry matter basis)

\begin{tabular}{lrc}
\hline \multicolumn{1}{c}{ Chemical composition } & Concentrate & $\begin{array}{r}\text { Brachiaria } \\
\text { humidicola }\end{array}$ \\
\hline Dry matter ${ }^{\mathrm{a}}(\%)$ & 87.16 & 20.81 \\
Ash $^{\mathrm{a}}(\%)$ & 5.64 & 7.29 \\
Crude protein $^{\mathrm{a}}(\%)$ & 20.41 & 12.88 \\
Ether extract $^{\mathrm{a}}(\%)$ & 8.05 & 0.76 \\
Crude fibre $^{\mathrm{a}}(\%)$ & 8.64 & 33.20 \\
Nitrogen free extract $^{\mathrm{a}}(\%)$ & 57.26 & 45.86 \\
Total digestible nutrient $^{\mathrm{b}}(\%)$ & 74.00 & 55.00 \\
\hline
\end{tabular}

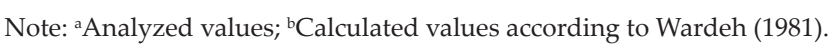


Table 2. The fatty acid composition of concentrate and forage (g/100g of total fatty acids)

\begin{tabular}{lcc}
\hline Fatty acids $^{\mathrm{a}}$ & Concentrate & $\begin{array}{c}\text { Brachiaria } \\
\text { humidicola }\end{array}$ \\
\hline Saturated fatty acids & 40.98 & 9.19 \\
Lauric acid (C12:0) & 21.49 & 1.03 \\
Myristic acid (C14:0) & 8.26 & 0.46 \\
Palmitic acid (C16:0) & 7.23 & 4.50 \\
Stearic acid (C18:0) & 3.25 & 1.21 \\
Arachidic acid (C20:0) & 0.18 & 0.59 \\
Behenic acid (C22:0) & 0.40 & 0.68 \\
Lignoceric acid (C24:0) & 0.17 & 0.72 \\
Unsaturated fatty acids & 38.98 & 9.89 \\
Mono-unsaturated fatty acids & 16.02 & 0.94 \\
Myristoleic acid (C14:1) & $*$ & 0.17 \\
Palmitoleic acid (C16:1) & 0.06 & 0.04 \\
Oleic acid (C18:1) & 15.96 & 0.73 \\
Poly-unsaturated fatty acids & 22.96 & 8.95 \\
Linoleic acid (C18:2) & 22.96 & 4.57 \\
Linolenic acid (C18:3) & $*$ & 4.38 \\
\hline
\end{tabular}

Note : *undefined; ${ }^{\text {A Analyzed values }}$

an Eppendorf tube then stored at $-20{ }^{\circ} \mathrm{C}$ until analysis. Blood malondialdehyde (MDA) concentration was determined by Rice-evans \& Anthony method (1991). Sampling and analysis were repeated on late pregnancy, lactation and weaning periods.

After birth, litter size, birth type, birth weight of lamb and lamb's mortality were recorded. The lambs were weighed within $24 \mathrm{~h}$. Lambs were weighed every week from the day of birth. The ewes weight difference before and after lambing was defined as the pre-lambing live weight change (LWC).

Milk production was measured by the estimation method based on the weight gain of lamb until it was reached 28 days old. Six $\mathrm{kg}$ of milk consumption is needed to produce $1 \mathrm{~kg}$ of lamb daily gain (Dove, 1988). The calculation was as follows:

Milk production $(\mathrm{g})$ = lamb average daily gain $(\mathrm{g}) \times 6$

Milk samples were collected from all ewes at 14, 28 , and $56 \mathrm{~d}$ of parturition. At the end of sampling, milk was composited. Samples were analyzed for the contents of total protein, lactose and density by means of Milkotester Master Pro.

\section{Statistical Analysis}

The blood MDA concentration, feed intake, prelambing live weight change (LWC), post-lambing average daily gain (ADG) and milk production of ewes were analyzed by ANOVA using SPSS statistical software. Any means differences were analyzed by Duncan's multiple range tests. Milk composition and performance of ewes and lamb were analyzed using descriptive analyzes.

\section{RESULTS AND DISCUSSION}

\section{Blood MDA Concentration}

Late pregnancy and early lactation were the critical period where the body metabolism increased. Ewe's ration containing PUFA was also very susceptible to induce lipid peroxidation. Unbalanced condition between free radicals and body antioxidant defense develops oxidative stress which can decrease immunity and health (Falowo et al., 2014). Consequently, it needs more exogenous antioxidant.

Blood MDA concentration in ewes along the trial period was presented in Table 3. The MDA concentrations between treatment was similar, however the highest downward trend occurred when the ewes fed ration added BTE compared to the other treatments. Blood MDA was reduced $0.3 \%$ in the late pregnancy, $7.4 \%$ in early lactation and $18.2 \%$ in weaning period when vit $\mathrm{E}$ was added into the ration, but BTE gave better results. It reduced $2.9 \%$ blood MDA concentration in late pregnancy, $44 \%$ in early lactation and $30.3 \%$ in weaning period.

Vit E and polyphenol of BTE as antioxidant work in many different ways such as scavenging free radicals, chain-carrying species in the lipid peroxidation, breaking chain propagation and binding metal ions (Niki et al., 2005; Lee et al., 2015). In this study, BTE was more effective to protect feed PUFA from free radical damage than vit E. This result persumably due to BTE has higher antioxidant activity than vit E. Plant extract polyphenol exhibited better antioxidant properties than vit $\mathrm{E}$ (Brenes et al., 2005; Goñi \& Serrano, 2005). So that the level of vit E on this study was not an effective level for supporting its antioxidant function.

Kuribayashi et al. (2010) stated that giving $600 \mathrm{mg} /$ $\mathrm{kg}$ diet of vit $\mathrm{E}$ as antioxidant source could reduce blood MDA and depress blood vessels damage on rabbits due to oxidative stress caused by corticosteroid induction. The blood MDA was higher than those reported by Duygu et al. (2011) and Bijan et al. (2012) who examined the blood MDA of infected sheep on recovery period. Nevertheless, other factors such as environment, temperature, feed and method of determination affected the blood MDA concentration. In this study, BTE was more effective to protect feed PUFA from free radical damage than vit $\mathrm{E}$.

Table 3. Blood MDA concentration on ewes fed different antioxidant sources along the trial period $(\mathrm{mg} / 100 \mathrm{~mL})$

\begin{tabular}{lccc}
\hline \multirow{2}{*}{ Periods } & \multicolumn{3}{c}{ Treatment } \\
\cline { 2 - 4 } & Control & Vit E & BTE \\
\hline Pre-treatment & $0.872 \pm 0.15$ & $0.756 \pm 0.00$ & $0.842 \pm 0.12$ \\
Late pregnancy & $0.653 \pm 0.15$ & $0.651 \pm 0.14$ & $0.634 \pm 0.15$ \\
Lactation & $0.983 \pm 0.12$ & $0.910 \pm 0.26$ & $0.545 \pm 0.01$ \\
Weaning & $0.711 \pm 0.36$ & $0.581 \pm 0.12$ & $0.495 \pm 0.07$ \\
\hline
\end{tabular}

Note: Control= basal diet without antioxidant source, vit $\mathrm{E}=$ basal diet supplemented with 500 ppm vitamin E, BTE= basal diet supplemented $500 \mathrm{ppm}(37.5 \mathrm{~g} / 100 \mathrm{~g}$ polyphenol) black tea extract; MDA= malondialdehyde. 


\section{Feed Intake, Pre-lambing Live Weight Change, and Post-lambing Average Daily Gain of Ewes}

The DM intake was not significant among the treatments (Table 4). It indicated that supplementation of vit E and BTE on high PUFA rations had no adverse effect on ewe's feed intake. Our results agreed with NRC (2006) that recommended 600-900 g/head/d of DM intake for pregnant ewes with $20-30 \mathrm{~kg}$ body weight. Different antioxidant sources had no effect on CP and TDN. It could be because of the rations were formulated in isoenergy and iso-protein so ewes fed the similar amount of nutrients.

A similar finding was reported by Zain (2009) who found the native grass substitution with ammoniated cocoa pod on sheep resulted similar nutrient intake due to the chemical composition of rations almost the same. Tillman et al. (1989) stated that nutrient intake was affected by physical form and chemical composition of feed, provision frequency as well as anti-nutrients. Phenolic acids, flavanoids and tannins, the most important polyphenol in plants which have antioxidant properties also can act as anti-nutrient because of its ability to bind many nutrients and affect their bioavailabity (Jakobek, 2015). Its astringent taste produce a feeling of roughness, dryness in the palate which decrease the palatability. Though we didn't measure the tannin content of BTE, our present study showed that the tannin content on 500 ppm BTE did not affect feed intake. Some previous studies showed that the level of tannins, kind of polyphenol had no effect on feed intake ( $\mathrm{Xu}$ et al., 2007; Salinas-Rios et al., 2015) while polyphenols were known to reduce feed intake by decreasing the palatability and/or ruminant turn over as well as the digestion, but it was influenced by the dosages.

There was no significantly different on pre-lambing LWC between treatments when antioxidant sources were given $(\mathrm{P}>0.05)$. This result was presumably due to the similar amount of DM intake. In current study, vit E

Table 4. Feed intake and live weight changes of ewes fed different antioxidant sources

\begin{tabular}{lrrr}
\hline & \multicolumn{3}{c}{ Treatment } \\
\cline { 2 - 4 } Parameters & $\begin{array}{c}\text { Control } \\
(\mathrm{n}=4)\end{array}$ & \multicolumn{1}{c}{$\begin{array}{c}\text { Vit E } \\
(\mathrm{n}=4)\end{array}$} & $\begin{array}{c}\text { BTE } \\
(\mathrm{n}=4)\end{array}$ \\
\hline $\begin{array}{l}\text { DM intake (g/head/d) } \\
\quad \text { Forage }\end{array}$ & $194.75 \pm 73.36$ & $170.62 \pm 49.30$ & $163.65 \pm 37.89$ \\
$\quad$ Concentrate & $593.90 \pm 31.15$ & $598.32 \pm 28.02$ & $635.32 \pm 29.21$ \\
$\quad$ Total & $788.65 \pm 76.47$ & $768.95 \pm 45.00$ & $798.98 \pm 65.91$ \\
CP intake (g/head/d) & $120.70 \pm 12.19$ & $118.19 \pm 7.21$ & $125.72 \pm 9.83$ \\
TDN intake (g/head/d) & $596.78 \pm 62.09$ & $580.19 \pm 65.43$ & $573.98 \pm 49.06$ \\
Pre-lambing LWC (kg) & $-7.50 \pm 0.21$ & $-6.20 \pm 1.25$ & $-8.50 \pm 2.65$ \\
$\begin{array}{l}\text { Post lambing ADG } \\
\text { (g/head/d) }\end{array}$ & $53.13 \pm 8.55$ & $51.79 \pm 19.09$ & $44.05 \pm 12.40$ \\
\hline
\end{tabular}

Note: Control= basal diet without antioxidant source, vit $\mathrm{E}=$ basal diet supplemented with 500 ppm vitamin E, BTE= basal diet supplemented 500 ppm (37.5 g/100g polyphenol) black tea extract; LWC= live weight change; $\mathrm{ADG}=$ average daily gain; $\mathrm{DM}=$ dry matter; $\mathrm{CP}=$ crude protein; $\mathrm{TDN}=$ total digestible nutrient; $\mathrm{n}=$ the number of ewes. supplementation tended to have the fewest pre-lambing LWC among others. This result indicates that the ewes on vit E treatment utilized feed nutrients for recovering their body condition in spite of producing milk. Antioxidant play an important role on protecting PUFA so it can be used as energy source and other function in the animal body. PUFA especially linoleic acid and $\alpha$ linolenic acid are the precursors of long-PUFAs (eicosapentanoic acid and arachidonic acid) synthesised. These fatty acids are the precursors for eicosanoic including prostaglandin which related to the fast uterine involution after lambing and ewes fertility (Gulliver et al., 2012; Cerri et al., 2009; Coyne et al., 2008).

The high pre-lambing LWC on both BTE supplementation and control treatments presumably due to their high milk production (Table 5). The period from $3 \mathrm{wk}$ before to $3 \mathrm{wk}$ after lambing were the important stage that the energy requirements for milk production and maintenance exceed the energy from feed intake (Esposito et al., 2014). This condition induce the physiological state of energy balance then resulting the higher weight lose of ewes.

Ewe's post-lambing ADG was not affected by the different antioxidant sources supplementation. Nutrient requirement of ewes at lactation phase was higher than other phases because it was used for milk production. This caused the negative impact on ADG of ewes in early lactation. ADG will increase after peak of lactation due to the decrease of milk production, so the nutrients used for weight gain (Freer \& Dove, 2002). The lowest ewes post lambing ADG on BTE treatment, presumably due to BTE treatment has higher milk production than vit E so the greater nutrient supply is needed. The nutrient was used to fulfill the requirement for producing milk, then its ADG declined. The nutrient supply didn't enought to provide the requirement to produce milk and increase ADG. In line with our study, Po et al. (2012) found that feeding Yerba mate (contained of polyphenol) dereased live weight in Dorper ewes in 1-7 wk of lactation period.

Table 5. Ewes milk production and composition fed different antioxidant sources

\begin{tabular}{|c|c|c|c|c|}
\hline \multirow{2}{*}{ Parameters } & \multicolumn{4}{|c|}{ Treatment } \\
\hline & Control $(\mathrm{n}=4)$ & Vit E & $\mathrm{n}=4)$ & BTE $(n=4)$ \\
\hline $\begin{array}{l}\text { Milk production } \\
(\mathrm{g} / \mathrm{head} / \mathrm{d})\end{array}$ & $1125.00 \pm 81.13^{\mathrm{a}}$ & $629.00 \pm 1$ & $07.85^{\mathrm{b}}$ & $1029.00 \pm 312.98^{\mathrm{a}}$ \\
\hline \multicolumn{5}{|l|}{ Milk composition } \\
\hline \multicolumn{5}{|l|}{ Protein } \\
\hline$\%$ & $5.52 \pm 0.58$ & $6.15 \pm$ & 0.15 & $6.12 \pm \quad 0.14$ \\
\hline g & $62.47 \pm 4.47^{a}$ & $38.66 \pm$ & $6.63^{\mathrm{b}}$ & $49.07 \pm 14.92^{\mathrm{b}}$ \\
\hline \multicolumn{5}{|l|}{ Lactose } \\
\hline$\%$ & $4.12 \pm 0.15$ & $4.77 \pm$ & 0.29 & $4.69 \pm \quad 0.03$ \\
\hline $\mathrm{g}$ & $46.63 \pm 3.34^{\mathrm{ab}}$ & $38.47 \pm$ & $6.60^{\mathrm{b}}$ & $53.60 \pm 12.28^{a}$ \\
\hline Density $\left(\mathrm{kg} / \mathrm{m}^{3}\right)$ & 1.037 & 1.043 & & 1.041 \\
\hline
\end{tabular}

Note: Means in the same row with different superscript differ significantly $(\mathrm{P}<0.05)$. Control= basal diet without antioxidant source, vit $\mathrm{E}=$ basal diet supplemented with $500 \mathrm{ppm}$ vitamin $\mathrm{E}, \mathrm{BTE}=$ basal diet supplemented $500 \mathrm{ppm}(37.5 \mathrm{~g} / 100 \mathrm{~g}$ polyphenol) black tea extract; $n=$ the number of ewes. ${ }^{*}$ Estimated values (Dove, 1988). 


\section{Milk Production}

Different antioxidant sources affect amount of milk production $(\mathrm{P}<0.05)$. Table 5 shows that both BTE and control treatments had higher milk production than vit E. There was no difference in the protein and lactose concentration as well as the density of milk. The supplementation of vit E significantly produced lower quantity of milk protein and lactose than other treatments $(\mathrm{P}<0.05)$. However, vit $\mathrm{E}$ increased the protein and lactose concentration of milk about $11.41 \%$ and $15.78 \%$ respectively versus the control treatment.

In agreement with Mutoni et al. (2012) who stated that milk production was increased when $1000 \mathrm{IU}$ of vit E was added on cows feed., but vit E supplementation on this study decreased the milk production (Table 5). The dosage of $50 \mathrm{mg}$ vit E injection at day 30 and 15 prior to the day of parturition reduce the milk somatic cell counts and also the udder infections, which induce the milk production (Qureshi et al., 2010).

Dosage of vit $\mathrm{E}$ as antioxidant source plays an important roles to maintain the oxidation balance in animal body. Level of vit E supplementation in our current study has not been able to prevent the amount of ROS which associated with mastitis disease and the decline of milk production (Celi, 2010). The reaction between ROS and cellular macro molecules, such as PUFA enhanced ephitelial abrassion and apoptosis on the udder (Suriyasataphorn et al., 2006). Furthermore, PUFA oxidation reduced the energy supply resulting the low milk production. Our results were in accordance with Pirestani et al. (2014) who found the supplementation of vit $\mathrm{E}$ and Se resulted less milk production than control treatment in cows.

The lower milk production also affected milk protein and lactose quantity. However its concentration as well as milk density were increased. This results might also have been the consequences of a lower milk production. Barrón-Bravo et al. (2013) found that goats with higher milk somatic cell score (indicating mastitis diseases) produced low milk yield and fat content, but higher protein content.

The BTE supplementation had similar milk production than control, but it also tended to have higher protein and lactose content as well as milk density than control. This result confirmed that BTE as a source of antioxidant maintained the oxidation balance in animal body. BTE contains of polyphenol which has antioxidant activity, such as catechin and theaflavin (Min et al., 2013; Carloni et al., 2013). Those compounds protected PUFA thus providing energy source and precursors of steroid hormones (glucocorticoids, progesterone and estradiol) which will stimulate the secretory cells of the mammary gland to increase milk production. Higher milk production is related to lactose levels due to lactose synthesis is the principal factor that determines the milk volume (Po et al., 2012). In our study, high milk production also influenced higher pre-lambing LWC and decreased ewes post-lambing ADG.

The BTE supplementation had higher milk protein and lactose than vit E. BTE polyphenol act as antioxidant prevent the oxidative status and retain the health of the mammary gland. It also increased the permeability of alveolus cell of mammary gland (Nurdin, 2004; Nurdin, 2007) thus increased the transfer of serum proteins into the mammary gland. Polyphenol also maintained the balance of rumen microbes (Nurdin, 2004). Protozoa, as bacteria predators, become the most deleterious effect on the efficiency of $\mathrm{N}$ use in the rumen. Antioxidant properties from polyphenol will change the microbes balance in the rumen by rid the pathogenic microbes so that the number of bacteria increase (Mardalena et al., 2014). This case will enhance microbial protein synthesis then increase amino acid flow to duodenum (Mueller-Harvey, 2006). Moreover, it supplied amino acids contributing milk protein synthesis.

Polyphenol also prevent PUFA as energy source so it can supply glucose to mammary gland which is important to produce milk lactose (Ramli et al., 2009). Aguiar et al. (2014) found that feeding phenolic compounds from propolis extracts had no effects on milk production of Holstein cows but increased the lactose and protein yield than control. Our results may also be attributed to the high concentrate diets which lead to decrease milk fat content because of the changes in fat synthesis (Chouinard et al., 1999; Loor et al., 2010). But our current study could't support this opinion, due to no milk fat data.

\section{Ewes and Lamb Performances}

The performance of ewes and lambs was reported in Table 6. Overall, the supplementation of antioxidants improved the lambing rate, the number of twin birth,

Table 6. Ewes and lamb performances fed different antioxidant sources

\begin{tabular}{lccc}
\hline \multirow{2}{*}{ Parameters } & \multicolumn{3}{c}{ Treatment } \\
\cline { 2 - 4 } & Control & Vit E & BTE \\
\hline The number of ewes (head) & 4 & 4 & 4 \\
Lambing rate (\%) & 150 & 225 & 175 \\
Type of birth (\%) & & & \\
$\quad$ Single & 50 & 25 & 50 \\
$\quad$ Twin & 50 & 75 & 50 \\
Mortality rate of twin lamb (\%) & 0 & 44.44 & 14.29 \\
Birth weight of lamb (kg) & & & \\
$\quad$ Single & $2.70(\mathrm{n}=2)$ & $2.40(\mathrm{n}=1)$ & $3.20(\mathrm{n}=2)$ \\
$\quad$ Twin & $2.10(\mathrm{n}=4)$ & $1.49(\mathrm{n}=8)$ & $1.60(\mathrm{n}=5)$ \\
$\quad$ Total & 13.8 & 14.32 & 14.4 \\
Weaning weight of lamb (kg) & & & \\
$\quad$ Single & $10.60(\mathrm{n}=2)$ & $7.40(\mathrm{n}=1)$ & $10.60(\mathrm{n}=2)$ \\
$\quad$ Twin & $6.85(\mathrm{n}=4)$ & $5.55(\mathrm{n}=4)$ & $6.45(\mathrm{n}=4)$ \\
$\quad$ Total & 48.6 & 29.6 & 47 \\
Weight gain of lamb & & & \\
(g/head/d) & & & \\
Single & & & \\
Twin & & & \\
Total & & & \\
\hline
\end{tabular}

Note: Control= basal diet without antioxidant source, vit $\mathrm{E}=$ basal diet supplemented with 500 ppm vitamin E, BTE= basal diet supplemented 500 ppm (37.5 g/100g polyphenol) black tea extract. 
and the birth weight of lambs. This result could indicate their function in reducing the oxidative stress on the animals and protect feed PUFA. PUFA is essential to produce progesterone in the body. It plays a role in protecting and maintaining the pregnancy, so that the embryo can well develop into a fetus and born safely. Gulliver et al. (2012) stated that PUFA reduced the PGF2 $\alpha$ synthesis and continued with progesterone secretion that might improve embryo survival and reduced embryo mortality.

Table 6 shows that vit E increased lambing rate and the case of twin birth. PUFA from sunflower oil influenced reproduction by supplying precursors of steroid hormones. Prostaglandin, one of steroid hormones is an important mediators of ovulation. Supplementation of antioxidant sources prevents PUFA from ROS oxidation so it can be used as energy source for supporting a multiple birth. Antioxidant supplementation can increases the antioxidant status of the reproductive tract which improve the fetal development on late pregnancy phase. Diet enriched with long chain n-3 PUFA resulted high ova release (Trujilo et al., 1995). El-Nour et al. (2012) stated that PUFA from calcium soap of fatty acid supplementation increased ovulation rate, follicle number and the pregnancy rate. Vit E could prevent negative effect of noise on the pregnancy rate and the rate of fetal death and abortion on female mice (Fathollahi et al., 2013).

The supplementation of BTE on ewes ration improved the lamb birth weight on single birth (Table 6). Antioxidant improved ewes immunity along the pregnancy period and supported the fetus development as well as increased the lamb birth weight. Twin birth was increased when vit E and BTE were added into the ration. Ewes with twin birth tended to produce lower lamb birth weight. This result is in agreement with Yilmaz et al. (2007). The low birth weight of twin lamb is most likely because there was competition between twins for placental nutrients and mothers milk when they were in maternal environment. Gardner et al. (2007) stated that birth weight was not only affected by the nutrient supply from mother to multiple litters, but also affected by the capacity of mother to bear multiple litters, forces in uterus and the fetal genotype. Maternal uterine space has optimum capacity to gestate offspring. If the litter size increase, the birth weight will be decline.

Antioxidant supplementation resulted in the upward trend on lamb mortality (Table 6). The higher mortality rate could be caused by the higher number of twin lambs than control which is resulting the longer birth process and the lower lamb weight. The case of mortality was higher in vit E than BTE. One ewe fed ration with vit E supplementation delivered 4 lambs but they were died due to the lower birth weight (0.8-0.9 $\mathrm{kg} / \mathrm{head})$. In the similar case, a lamb (1.2 kg/head) was died when delivered process of ewes fed ration with BTE supplementation. Both antioxidant supplementations were given on the late pregnancy period so that we can not control the number of embrio. We infered that vit E can not protect PUFA from oxidation process, then the energy supply did not fulfilled with the energy requirement to support the development of more than two fetuses.

Chniter et al. (2011) reported that mortality rate in single birth lambs was low. Higher mortality may be associated with the low birth weight of lambs from large litter size. After birth, survival of the newborn depends largely upon the interactions quality with the mother, the amount of available milk and the competition with siblings as well as diseases (Nowak \& Poindron, 2006). The competition in obtaining colostrums on twin lambs made them not get enough nutrients on early birth and then decreased the survival rate .

Growth of lamb is largely dependent on the nutrients of milk from their mother during 4 weeks of life. The higher weaning weight of lamb suggest the better lactation performances of ewes. Table 6 showed that BTE treatment had similar body weight and weight gain of single and twin lambs at weaning period, and vit $\mathrm{E}$ had the lowest one. It is likely that lambs growth was affected by dietary treatments. Fereira et al. (2014) found the increased of weaning weight was linear with the milk production of ewes. There was a relationship between the amount of ewe's milk production and weaning performances of lamb in the pre-weaning phase (Aroujo et al. 2008; Jarmuji, 2010).

This study found that vit E supplementation produced less milk than others. The low milk production could be the reason for the low body weight and weight gain of lamb on vit E supplementation treatment. Amount of milk production associated with the lamb's opprotunity to consume immunoglobulin and antioxidant. A healthy immune system of mother's will be transferred to the child through placenta and breast milk, including colostrum. Milk that contained enhancement growth factor and immunoglobulin will affect the health and growth rate of the offspring (Akbar, 2013).

Despite of higher milk production in BTE supplementation, the higher weaning weight of lamb could be caused by the polyphenol content in milk. Po et al. (2012) stated that milk production and its quality are critical factors for the survival and growth of lamb. Di Trana et al. (2015) found the positive correlation between polyphenol intake and milk polyphenol content in goats. Increasing level of antioxidant in parent's ration resulted high antioxidant content in milk. Antioxidant act as a radical scavenger, hydrogen and electron donor, peroxide decomposer, singlet oxygen quencher, enzyme inhibitor as well as metal-chelating agents (Lobo et al., 2010). It plays an important role in immune responses, thus increase the growth rate of lambs.

\section{CONCLUSION}

The supplementation of black tea extract was more effective to decrease blood malondialdehyde concentration of ewes. However, black tea extract and vitamin E supplementation gave similar respond to ewes reproductive performances. Vitamin E supplementation reduced the milk production of ewes. 


\section{ACKNOWLEDGEMENT}

This study was funded by "BOPTN" Grant No. 2013.089.521219 from Directorate General of Higher Education, Ministry of National Education of Indonesia. Authors would like to thank Prof. Komang G. Wiryawan for reading the manuscript.

\section{REFERENCES}

Aguiar, S. C., S. M. Cottica, J. S. Boeing, R. B. Samensari, G. T. Santos, J. V. Visentainer, \& L. M. Zeoula. 2014. Effect of feeding phenolic compounds from propolis extracts to dairy cows on milk fatty acid composition and the antioxidant capacity of milk. Anim. Feed Sci. Technol. 193: 148154. http://dx.doi.org/10.1016/j.anifeedsci.2014.04.006

Akbar, M., O. Sjofjan \& S. Minarti. 2013. Milk production of rabbit doe and kit mortality as affected by dietary katuk leaf meal (Sauropus androgynus L. Merr). JITV 18: 233-238. http://dx.doi.org/10.14334/jitv.v18i4.326

Akhadiarto, S. \& N. Rofiq. 2008. Pengaruh pemberian ransum yang mengandung tepung kunyit terhadap pertambahan bobot badan domba induk dan bobot lahir anak. J. Indon. Trop. Anim. Agric. 33: 268-273.

AOAC. 2005. Official Methods of Analysis of AOAC International. 18th ed. Assoc. Off. Anal. Chem., Maryland.

Ayala, A., M. F. Mu-oz \& S. Argüelles. 2014. Lipid peroxidation: production, metabolism and signaling mechanisms of malondialdehyde and 4-Hydroxy-2-nonenal. Oxid. Med. Cell Longev. 2014: 1-31. http://dx.doi.org/10.1155/2014/360438

Araujo, R. C., A. V. Pires, I. Susin, C. Q. Mendes, G. H. Rodrigues, I. U. Packer \& M.I. Eastridge. 2008. Milk yield, milk composition, eating behaviour and lamb performance of ewes fed diets containing soybea hulls replacing coats cross (Condon sp.) hay. Anim. Sci 86: 3511-3521. http://dx.doi.org/10.2527/jas.2008-0940

Barrón-Bravo, O. G., A. J. Gutiérrez-Chávez, C. A. ÁngelSahagún, H. H. Montaldo, L. Shepard \& M. ValenciaPosadas. 2013. Losses in milk yield, fat and protein contents according to different level of somatic cell count in dairy goats. Small Rum. Res. 113: 421-431. http://dx.doi. org/10.1016/j.smallrumres.2013.04.003

Bhale, D. V., M. D. Hivre, R. K. Mahat \& A. A. Bujurge. 2014. Comparative study of serum malondialdehyde levels as a marker of oxidative stress in patients of pregnancy-induced hypertension and controls. MGM J. Med. Sci. 1: 5355. http://dx.doi.org/10.5005/jp-journals-10036-1010

Bhuyar, B. K. \& M. Shamsuddin. 2014. Study of serum malondialdehyde and ascorbic acid levels in pre-eclampsia. Int. J. Biol. Med. Res. 5: 4163-4168.

Bijan, E., T. Mosa, A. R. Siamak \& D. N. Bahram. 2012. Evaluation of antioxidant status and oxidative stress in sheep naturally infected with babesiaovis. Vet. Parasitol. 185:124130. http://dx.doi.org/10.1016/j.vetpar.2011.10.001

BPOM. 2004. Monografi ekstrak tumbuhan obat Indonesia $1^{\text {st }}$ ed. Badan POM R.I., Jakarta.

Brenes, A., A. Viveros, I. Goñi, C. Centeno, S. G. Sáyago-Ayerdy, I. Arija \& F. Saura-Calixto. 2008. Effect of grape pomace concentrate and vitamin $\mathrm{E}$ on digestibility of polyphenols and antioxidant activity in chickens. Poult. Sci. 87: 307-316. http://dx.doi.org/10.3382/ps.2007-00297

Capper, J. L., G. W. Robert, K. Eleni, E. P. Sandra, M. M. Alexander \& A. S. Liam. 2005. The effect of dietary vitamin E and fatty acid supplementation of pregnant and lactating ewes on placental and mammary transfer of vitamin $\mathrm{E}$ to the lamb. J. Nutr. 93: 549-557. http://dx.doi.org/10.1079/ BJN20051376
Carloni, P., L.Tiano, L. Padella, T. Bacchetti, C. Customu, A. Kay \& E. Damiani. 2013. Antioxidant activity of white, green and black tea obtained from the Sam tea cultivar. Food Res. Int. 53: 900-908. http://dx.doi.org/10.1016/ j.foodres.2012.07.057

Celi, P. 2010. The role of oxidative stress in small ruminants health and production. R. Bras. Zootec. 39 : 348-363. http:// dx.doi.org/10.1590/S1516-35982010001300038

Cerri, R. L. A., S. O. Juchem, R. C. Chebel, H. M. Rutigliano, R. G. S. Bruno, K. N. Galvao, W. W. Thatcher, \& J. E. P. Santhos. 2009. Effect of fat source differing in fatty acid profile on metabolic parameters, fertilization and embryo quality in high producing dairy cows. J. Dairy Sci. 92: 1520-1531. http://dx.doi.org/10.3168/jds.2008-1614

Chniter, M., M. Hammadi, T. Khorchani, R. Krit, B. Lahsoumi, M. B. Sassi, R. Nowak, \& M. B. Hamouda. 2011. Short communication: Phenotypic and seasonal factors influence birth weight, growth rate and lamb mortality in D'man sheep maintained under intensive management in Tunisian oases. Small. Rum. Res. 99:166-170. http://dx.doi. org/10.1016/j.smallrumres.2011.03.046

Chouinard, P. Y., L. Corneau, D. M. Barbano, L. E. Metzger, \& D. E. Bauman. 1999. Conjugated linoleic acids alter milk fatty acid composition and inhibit milk fat secretion in dairy cows. J. Nutr. 129 : 1579-1584.

Coyne, G. S., D. A. Kenny, S. Childs, J. M. Sreenan \& S. M. Waters. 2008. Dietary n-3 polyunsaturated fatty acids alter the expression of genes involved in prostaglandin biosynthesis in the bovine uterus. Theriogenology. 70: 772-782. http://dx.doi.org/10.1016/j.theriogenology.2008.05.048

Di Trana, A., A. Bonanno, S. Cecchini, D. Giorgio, A. Di Grigoli \& S. Claps. 2015. Effects of Sulla forage (Sulla coronarium L.) on the oxidative status and milk polyphenol content in goats. J. Dairy Sci 98: 37-46. http://dx.doi.org/10.3168/ jds.2014-8414

Dove, H. 1988. Estimating the intake of milk by lambs, from the turn over of deuterium or tritium labelled water. Br. J. Nutr. 60: 375-387. http://dx.doi.org/10.1079/BJN19880107

Duygu, N. S. I., E. S. Cem, \& G. Mehmet. 2011.The investigation of lipid peroxidation antioxidan levels and some hematological parameters in sheep naturally infested with wohlfahrtiamagnifica larvae. Vet. Parasitol.18:112-118.

El-Nour, H. M. M., S. M. Nasr, \& W. R. Hassan. 2012. Effect of calcium soap of fatty acids suplementation on serum biochemical parameters and ovarian activity during out-ofthe breeding season in crossbred ewes. Sci. World J. 2012: 1-7.

Esposito, G., P. C. Irons, E. C. Webb, \& A. Chapwanya. 2014. Interactions between negative energy balance, uterine health and immune response in transition dairy cows. Anim. Repro. Sci. $144: 60-71$

Falowo, A.B., P. O. Fayemi \& V. Muchenje. 2014. Natural antioxidantsagainst lipid-protein oxidative deterioration in meat and meat products: A review. Food Res. Int. 64: 171181. http://dx.doi.org/10.1016/j.foodres.2014.06.022

Fathollahi, A., M. Jasemi, \& G. Saki. 2013. Effect of noise stress on male rat fertility and the protective effect of vitamins C and E on its potential effect. Arab J. Urol. 11: 101-105. http://dx.doi.org/10.1016/j.aju.2012.12.002

Ferreira, E. M., A. V. Pires, I. Susin, R. S. Gentil, S. Gilaverte, M. D. M. Parente, M. V. Biehl, \& C. V. D. Ribeiro. 2014. Lamb performance, milk production and composition from ewes supplemented with soybean oil partially replaced by fish oil blend. Livestock Sci. 163: 51-61. http:// dx.doi.org/10.1016/j.livsci.2014.02.009

Freer, M. \& H. Dove. 2002. Sheep Nutrition. CABI Publishing, Collingwood. 
Frei, B. \& J. V. Higdon. 2003. Antioxidant activity of tea polyphenols in vivo: Evidence from animal studies. J. Nutr. 133: 3275-3284.

Gardner, D. S., P. J. Buttery, Z. Daniel, \& M. E. Symonds. 2007. Factors affecting birth weight in sheep : maternal environment. Reprod. 133: 297-307. http://dx.doi.org/10.1530/REP06-0042.

Goñi, I. \& J. Serrano. 2005. The intake of dietary fiber from grape seeds modifies the antioxidant status in rat cecum. J. Sci. Food Agric. 85: 1877-1881. http://dx.doi.org/10.1002/ jsfa.2213

Gulliver, C. E., M. A. Friend, B. J. King, \& E. H. Clayton. 2012. The role of omega-3 polyunsaturated fatty acids in reproduction of sheep and cattle. Review article. Anim. Reprod. Sci. 131 : 9-22. http://dx.doi.org/10.1016/j.anireprosci.2012. 02.002

Hidayah, N., S. Suharti \& K. G. Wiryawan. 2014. In vitro rumen fermentation of ration supplemented with protected vegetable oils. Med. Pet. 37: 129-135. http://dx.doi.org/10.5398/ medpet.2014.37.2.129

Jakobek, L. 2015. Interactions of polyphenols with carbohydrates, lipids and proteins. Food Chem. 175: 556-567. http://dx.doi.org/10.1016/j.foodchem.2014.12.013

Jarmuji. 2010. Produksi susu induk terhadap pengaruh pertambahan bobot badan, bobot sapih dan daya hidup anak domba ekor tipis jawa periode prasapih. J. Sains Pet. Indon. 5: 34-42.

Kuribayashi, M., M. Fujioka, K. A. Takahashi, Y. Arai, M. Ishida, \& T. Goto. 2010. Vitamin E prevents steroid-induced osteonecrosis in rabbits. Acta Orthop. 81:154-60. http:// dx.doi.org/10.3109/17453671003628772

Lee, C. Y., C. N. Nanah, R. A. Held, A. R. Clark, U. G. T. Huynh, M. C. Maraskine, R. I. Uzarski, J. McCracken \& A. Sharma. 2015. Effect of electron donating groups on polyphenol-based antioxidant dendrimes. Biochimie. 111: 125-134. http://dx.doi.org/10.1016/j.biochi.2015.02.001

Lobo, V., A. Patil, A. Phatak, \& N. Chandra. 2010. Free radicals, antioxidants and functional foods: Impact on human health. Pharmacogn. Rev. 4: 118-126. http://dx.doi. org/10.4103/0973-7847.70902

Loor, J. J., A. Ferlay, A. Ollier, M. Doreau, \& Y. Chilliard. 2010. Relationship among trans and conjugated fatty acids and bovine milk fat yield due to dieatry concentrate and linseed oil. J. Dairy Sci. 88: 726-740. http://dx.doi.org/10.3168/ jds.S0022-0302(05)72736-3

Mardalena, S. Novianti, Yurleni, \& U. Amri. 2014. Evaluation of feed supplement as antioxidant source on rumen ecology. Pak. J. Nutr. 13: 381-385. http://dx.doi.org/10.3923/ pin.2014.381.385

Min, H. P., S. L. Ching, H. Wang, Y. L. Cu, T. H. Chi, \& S. Li. 2013. Black tea in chemo-prevention of cancer Ana other human diseases. Feed Sci. Human Wellness 2: 12-21. http:// dx.doi.org/10.1016/j.fshw.2013.03.004

Mueller-Harvey, I. 2006. Review, unraveling the conundrum of tannins in animal nutrition and health. J. Sci. Food Agric. 86 : 2010-2037. http://dx.doi.org/10.1002/jsfa.2577

Murray, R. K., D. K. Granner, P. A. Mayes \& V. W. Rodwell. 1993. Harper's Biochemistry. $23^{\text {rd }}$ ed. Appleton and Lange. Norwalk.

Mutoni, G., S. Prassad, K. De, S. Pal, J. Mukherjee, S. Kapila, H. Kaur, A. K. Mohanty, \& A. K. Dan. 2012. Effect of supplementation vitamin E, copper and zinc around peripartum on udder health, milk yield and composition of Sahiwal cows. Livestock Res Rur Dev. 24: Article \#220. Retrieved December 21, 2014, from http://www.lrrd.org/ lrrd24/12/muto24220.htm

Niki, E., Y. Yoshida, Y. Saito \& N. Noguchi. 2005. Lipid peroxidation: Mechanisms, inhibition and biological effects. Bio- chem. Biophysic. Res. Comm. 338: 668-676. http://dx.doi. org/10.1016/j.bbrc.2005.08.072

Nowak, R. \& P. Poindron. 2006. From birth to colostrum: early steps leading to lamb survival. Reprod. Nutr. Dev. 46: 431446. http://dx.doi.org/10.1051/rnd:2006023

NRC. 2006. Nutrient Requirement of Sheep. National Academy Pr., Washington DC

NRC. 2007. Nutrient Requirements of Small Ruminants 1st ed. National Academy Pr., Washington DC.

Nurdin, E. 2004. Efek pemberian bioplus-Se dan bunga matahari terhadap ekologi rumen sapi perah FH. JPL Faterna. 10: 64-67.

Nurdin, E. 2007. Pengaruh pemberian tongkol bunga matahari (Helianthus annuus L.) dan probiotik terhadap penurunan derajat mastitis pada sapi perah Fries Holland penderita mastitis sub klinis. J. Indon. Trop. Anim. Agric. 32: 76-79.

Po, E., Z. Xu, \& P. Celi. 2012. The effect of Yerba mate (Ilex paraguarensis) supplementation on the productive performance of Dorper ewes and their progeny. Asian-Aust. J. Anim. Sci. 25: 945-949.

Qureshi, Z. I., M. Siddiq, L. A., Lodhi, G. Muhammad, \& H. Jamil. 2010. Effect of vitamin E-selenium administration during late gestation on productive and reproductive performance in dairy buffaloes and on growth performance of their calves. Pakistani. Vet. J. 30: 83-86.

Ramli, N., M. Ridla, T. Toharmat, \& L. Abdullah. 2009. Produksi dan kualitas susu sapi perah dengan pakan silase ransum komplit berbasis sumber serat sampah sayuran pilihan. J. Indon. Trop. Anim. Agric. 34: 36-41.

Rao, P. S., S. Kalva, A. Yerramilli, \& S. Mamidi. 2011. Free radicals and tissue damage: Role of antioxidants. Free Rad. Antiox. 1: 2-7.

Rice-Evans, C., T. D. Anthony, \& M. C. R. Symons. 1991. Techniques In Free Radical Research. Elsevier, Amsterdam.

Salinas-Rios, T., M. E. Ortega-Cerrilla, M. T. Sánchez-Torres-Esqueda, J. Hernández-Bautista, A. Díaz-Cruz, J. L. Figueroa-Velasco, R. Guinzberg-Perrusquía, \& J. L. Cordero-Mora. 2015. Productive performance and oxidative status of sheep Red diet suplementer Alt Coffee pulp. Small Rum. Res. 123 : 17-21. http://dx.doi.org/10.1016/j.sm allrumres.2014.09.008

Sgorlon, S., G. Stradaioli, D. Zanin, \& B. Stefanon. 2006. Biochemical and Molecular responses to antioxidant supplementation in sheep. Small. Rum. Res. 64: 143-151. http:// dx.doi.org/10.1016/j.smallrumres.2005.04.009

Shahidi, F. 2009. Nutraceuticals and functional foods: whole versus processed foods.Trends Food Sci.Technol. 20: 376387. http://dx.doi.org/10.1016/j.tifs.2008.08.004

Suriyasathaporn, W., U. Vinitketkumnuen, T. Chewonarin, S. Boonyayatra, K. Kreausukon, \& Y. H. Schukken. 2006. Higher somatic cell counts resulted in higher malondialdehyde concentrations in raw cows' milk. Intl. Dairy J. 16: 1088-1091. http://dx.doi.org/10.1016/j.idairyj.2005.11.004

Tillman, A.D., H. Hartadi, S. Reksodiprodjo, S. Prawirokusomo \& L. Lebdosoekojo. 1989. Ilmu Makanan Ternak Dasar. Gajah Mada University Press, Yogyakarta.

Trujillo, E. P. \& K.S. Broughton. 1995. Ingestion of n-3 polyunsaturated fattyacids and ovulation in rats. J. Reprod. Fertil. 105:197-203. http://dx.doi.org/10.1530/jrf.0.1050197

Wang, Z., C. Fu, \& S. Yu. 2011. Green tea polyphenols added to IVM and IVC media affect transcript abundance, apoptosis and pregnancy rated in bovine embryos. Theriogenology 79: 186-192. http://dx.doi.org/10.1016/j.theriogenology.201 2.10.002

Wardeh, M. F. 1981. Models for estimating energy and protein utilization for feeds. Ph.D. Thesis, Utah State University. Logan, Utah, USA.

Xu, C., Y. Cai, N. Moriya, \& M. Ogawa. 2007. Nutritive val- 
ue for ruminants of green tea grounds as a replacement of brewers' grains in totally mixed ration silage. Anim. Feed Sci. Technol. 138: 228-238. http://dx.doi.org/10.1016/ j.anifeedsci.2006.11.014

Yang, L. Y., X. S. Li, B. X. He, X. L. Yang, G. H. Li, P. Liu, Q. H. Huang, X. M. Pan \& J. Li. 2011. Malondialdehyde level and some enzymatic activities in subclinical mastitis milk. Afr. J. Biotechnol. 10: 5534-5538.
Yilmaz, O., H. Denk, \& D. Bayram. 2007. Effects of lambing season, sex and birth type on growth performance in Norduz lambs. Technical Note. Small Rumin. Res. 68: 336-339. http://dx.doi.org/10.1016/j.smallrumres.2005.11.013

Zain, M. 2009. Substitusi rumput lapangan dengan kulit buah coklat amoniasi dalam ransum domba lokal. Med. Pet. 32: 47-52. 